IZA DP No. 6907

Intergenerational Income Persistency in Urban China

Deng Quheng

Björn Gustafsson

Li Shi

October 2012

Forschungsinstitut zur Zukunft der Arbeit Institute for the Study of Labor 


\title{
Intergenerational Income Persistency in Urban China
}

\author{
Deng Quheng \\ Chinese Academy of Social Sciences
}

Björn Gustafsson

University of Gothenburg

and IZA

Li Shi

Beijing Normal University

and IZA

\section{Discussion Paper No. 6907 \\ October 2012}

\author{
IZA \\ P.O. Box 7240 \\ 53072 Bonn \\ Germany \\ Phone: +49-228-3894-0 \\ Fax: +49-228-3894-180 \\ E-mail: iza@iza.org
}

Any opinions expressed here are those of the author(s) and not those of IZA. Research published in this series may include views on policy, but the institute itself takes no institutional policy positions. The IZA research network is committed to the IZA Guiding Principles of Research Integrity.

The Institute for the Study of Labor (IZA) in Bonn is a local and virtual international research center and a place of communication between science, politics and business. IZA is an independent nonprofit organization supported by Deutsche Post Foundation. The center is associated with the University of Bonn and offers a stimulating research environment through its international network, workshops and conferences, data service, project support, research visits and doctoral program. IZA engages in (i) original and internationally competitive research in all fields of labor economics, (ii) development of policy concepts, and (iii) dissemination of research results and concepts to the interested public.

IZA Discussion Papers often represent preliminary work and are circulated to encourage discussion. Citation of such a paper should account for its provisional character. A revised version may be available directly from the author. 


\section{ABSTRACT \\ Intergenerational Income Persistency in Urban China}

Intergenerational income elasticities are estimated using samples for urban China (covering many cities) for the years 1995 and 2002 and compared with results from other studies. We find that the income relation between the pairs: sons and fathers, sons and mothers and daughters and mothers, are in 2002 all similar in magnitude. In contrast the relation between daughters' and fathers' income is weaker. The income relationship between offspring and mothers was weaker in 1995 than in 2002. Our preferred estimates of income persistency for the son-father pairs of 0.47 for 1995 and 0.53 for 2002 are higher than what has been reported in the literature for several high-income countries with large welfare states. The strength of the income link between sons and fathers in urban China appears to be not very different from what has been reported for countries such as Brazil, Chile and the United States.

JEL Classification: D31, J62, P32

Keywords: intergenerational income mobility, China

Corresponding author:

Björn Gustafsson

Department of Social Work

University of Gothenburg

P.O. Box 720

40530 Göteborg

Sweden

E-mail: Bjorn.Gustafsson@socwork.gu.se

\footnotetext{
* A first draft of this paper was presented at the $28^{\text {th }}$ General Conference of The International Association for Research in Income and Wealth, Cork, Ireland and we wish to thank Miles Corak for comments on that version. A previous version of the paper was presented at the $26^{\text {th }} \mathrm{ESPE}$ Conference in Bern, Switzerland. Quheng Deng would like to thank the Ontario Research Fund for financially supporting his visit to University of Western Ontario where part of the revision work was done. The work was supported by grants from The Swedish Research Council and The Swedish International Development Cooperation Agency (Sida): Swedish Research Links and The project of Integration of Urban and Rural Labour Market in China (70933001), supported by China Foundation of Natural Sciences. Authors are listed alphabetically by family name.
} 


\section{Introduction}

The income or earnings relation between members of two generations has received considerable attention in recent applied research. Regressing log income (alternatively log earnings) of sons and/or daughters on its counterpart defined for fathers and/or mothers provides a measure of association: the intergenerational income elasticity. A high positive value, typically lower than 1 , indicates large inequality of opportunities due to social connections, family investments and the genetic transmission of ability. Conversely, a low elasticity indicates low inequality in circumstances a person cannot affect. Constituting one single number, intergenerational income elasticity has attracted wide interest as a measure of intergenerational income persistency. However, as stressed by Roemer (2004), intergenerational income elasticity can be a noisy measure of inequalities that most people believe policy should minimize, as family background can affect the formation of preferences and aspirations of children, leading to differences in efforts.

Research conducted over the years has shown that establishing reliable estimates on intergenerational income elasticity is far from a trivial exercise (Solon, 1992 and Zimmerman, 1992). Samples used are often small, and results are often found to be sensitive to selection criteria (Couch and Lillard, 1998). Further, data at hand often do not match the concept researchers propose. While researchers typically are interested in the intergenerational elasticity of persistent income, available data often relate to one year only. Samples available are often from a small population group with great homogeneity and are not necessarily representative for the population in the country. It can also be troublesome that the two generations analysed might not be observed during the same stage in the life cycle (Grawe, 2006). A further problem is that analysts might only observe a subsample of the first generations, i.e., only those who co-reside with their children, thus leading to inconsistency of 
the estimate of intergenerational mobility. If parental information is reported in the data also for those who do not co-reside with their children, this sample selection bias can be corrected by, for example, the Heckman model (Francesconi and Nicoletti, 2006). There are also often problems with missing variables as income of the first or second generation might not be observed in one sample, leading researchers to fill in the missing data using information from other samples by a Two-Sample Two-Stage Least Squares (TS2SLS) approach (Björklund and Jäntti, 1997). ${ }^{1}$

The literature surveys by Solon (2002), Corak (2006), Björklund and Jäntti (2009) and Blanden (2011) show that many studies of intergenerational income persistency in the United States have been made, and there are also several studies for a number of other high-income countries. Most work has been done on the relation between income or earnings of sons and fathers. Among rich countries, the United States appears at one pole with low intergenerational income mobility, while Canada and the Nordic countries are found at the other. Outside the circle of high-income countries, studies on intergenerational income persistency are much less numerous. For example, the most populous country in the world, the People's Republic of China, has attracted little attention in the literature on intergenerational income elasticities. The purpose of this paper is to provide a new measure of intergenerational income elasticity of urban China that considers several of the methodolical issues addressed in the literature. Aiming to obtain robust results we use samples covering large parts of urban China; samples that have been similarly designed for 1995 and 2002.

Urban China differs from most high-income countries regarding the female labour force participation rate, as it is almost as high as the rate for males. Further, the gender earnings gap

\footnotetext{
${ }^{1}$ Fortunately, our data does not have this problem so we do not need to use the TS2SLS method.
} 
in China is smaller than in many other countries. It naturally follows that it is meaningful to study not only the relation between incomes of sons and fathers, but also the relation between incomes of daughters and fathers and offspring and mothers.

What kind of results can we expect to find? Solon (2004) provides a framework useful for arranging different circumstances of possible relevance and their importance. "One out of four" is the government's investment in child human capital through, for example, provision of education. Tertiary education has expanded rapidly in China after reform and opening up. The average number of college graduates in 10,000 persons has increased from 8.9 in 1978 to 70.3 in 2002 (NBS, 2004). Based on these facts only, one would expect to find low intergenerational income elasticity in our samples.

However, there are undoubtedly more aspects to the story of intergenerational income persistency in urban China, aspects that suggest that intergenerational income elasticity must not necessarily be low. From being low during the planning époque, rates of return to education are on the rise in China, which would taken separately in the framework of Solon (2004), increase intergenerational income persistency across samples. ${ }^{2}$ Speaking for intergenerational links being relatively high is the widespread opinion that social networks are important in China, and can to a varying degree be critical for obtaining the first job as well as job promotions. ${ }^{3}$ By and large, families play a significant role in the life of people in China, a role larger than in northern Europe, for example. In urban China, adult children typically live with their parents until marriage, and sometimes after, see Figure 1. Chinese parents as well

\footnotetext{
${ }^{2}$ The other two circumstances in the framework of Solon (2004) are the "mechanic" (for example genetic) transmission of income-generating traits and the efficiency of investments in children's human capital. Zhang et al. (2005) report that returns to education in urban China increase from 4.0 percent in 1988 to 10.2 percent in 2001. Sicular et al. (2007) also document the increase in returns to education in China.

${ }^{3}$ On the role of social capital in the Chinese labour market see for example Knight and Yueh (2008). Chen and Feng (2009) report that keeping a child's education constant, the father's education had a strong positive effect on earnings on the first job.
} 
as grandparents are known to invest considerable time and resources in the development of their offspring (see for example Croll, 2006, Chapter 7).

Turning to results, this study reports preferred estimates of the intergenerational income elasticity in urban China for sons and fathers that are corrected for co-residency bias and are based on income observed over a three-year period: these are 0.45 for 1995 and 0.51 for 2002 . For 2002, we find that the income relation between pairs of sons and fathers, sons and mothers, and daughters and mothers are all relatively similar in magnitude, while the relationship between income of daughters and fathers is somewhat weaker. The income relationship between offspring and mothers was weaker in 1995 than in 2002. Our preferred estimates for the son-father pairs for urban China are higher than what has been reported in the literature for several high-income countries with large welfare states. The strength of the income link between sons and fathers in urban China does not differ greatly from what has been reported from countries such as Brazil, Chile and the United States.

The rest of the paper is laid out as follows: In the next section we present our data and in Section 3 results. In order to investigate robustness of the results we make some analyses that are reported in Section 4. We put our findings in perspective by comparing them with findings reported in two other studies for urban China as well as from other countries in Section 5, and we sum up the findings in Section 6.

\section{Data and structure of the analysis}

Our data comes from the urban surveys of the China Income Distribution Project (CHIP), a collaboration between researchers at the Institute of Economics, Chinese Academy of Social 
Sciences, Beijing and researchers from other countries. In this project, researchers designed questionnaires while the fieldwork was carried out by the National Bureau of Statistics (NBS). We use surveys that collected information for 1995 and 2002. Both surveys were drawn from larger samples that NBS used for producing official statistics for China.

The 1995 survey covers 69 cities of varying sizes located in 11 province level units (Beijing, Shanxi, Liaoning, Jiangsu, Anhui, Henan, Hubei, Guangdong, Sichuan, Yunnan and Gansu), chosen to be representative of the eastern, central and western regions. The 2002 survey is rather similar as it covers 70 cities in the same province level units with the addition of Chongqing, which was earlier part of Sichuan. For more information on these two surveys see Li et al. (2008). The two surveys target the registered population, as do all other official statistics on urban China, but not rural people living in the cities without a registration permit (Hukou).

/Figure 1 about here/

In both surveys we can observe complete son/daughter - father/mother pairs and their income only in cases where the two generations co-reside. Our data, see Figure 1, shows that coresidence is rather common at age 25 , decreases with age most rapidly among daughters, and is uncommon among persons close to age 35. The special feature of the 2002 data of relevance to our study is that it provides some information about parents who do not live with their adult child/children. Although it does not report income of parents not co-residing with their children, information of parental age is provided, which enables us to limit the sample to parents aged 50 to 60 (even if they do not live together with their children) and then estimate the Heckman model. 
For our baseline estimates we select persons who were aged 25 to 35 for the second generation. The lower age restriction is motivated by the desire to exclude people who are at the start of their careers, the period in which income is a rather poor measure of lifetime permanent income. The higher age restriction is set to mitigate the problem of overrepresentativeness of children living separated from their parents at later ages.

By using the age interval 25 to 35 years, we are left with a sample with enough numbers of observations for statistical inference. To consider life cycle influence we also require that the first generation be aged 50 to 60 when we observe its income in our baseline estimates. The lower age limit forces us to drop only a few individuals. The upper age limit is motivated by the fact that almost all parents have left working life at age 60, and that the income generation process is therefore different from that which took place previously. The importance of this sample restriction is investigated in the sensitivity analysis reported in Section 4. We also require that individuals in both generations have a positive income in order to be in the sample.

With these restrictions we arrive at a sample size for the baseline estimates of at most 557 for the 1995 sample and 655 for the 2002 sample. As co-residence is more frequent for boys than girls, we have a larger number of sons in the samples. The number of mothers is larger than that of fathers, which is due to wives usually being younger than husbands in China and thus more likely to be in the age category 50-60 with children aged $25-35{ }^{4}$ As in the literature we are a part of is our ambition to describe the empirical relation between incomes of individuals

\footnotetext{
${ }^{4}$ In our 2002 data, the average age difference between a child and his/her father is 29 years while that between a child and his/her mother is 26 years.
} 
in two generations, not seeking a causal estimate of the effect of parental income on child's income.

In the analysis we will first relate income of offspring to income of fathers and income of mothers, respectively. Most analyses are made separately for all four pairs: son/father, son/mother, daughter/-father and daughter/-mother. As co-residency probably is not random, we will investigate the implications for our research questions. To address possible life cycle biases we also investigate to what extent including age in the regression analysis and defining the sample differently regarding age affects the estimated intergenerational income elasticity. To find out whether the intergenerational mobility exhibits the same pattern across the income distribution, we also use quantile regressions to estimate intergenerational income persistence.

Our target variable is personal income defined as the sum of earnings, business and capital income and refers to 1995 and 2002, respectively. Income is measured before income taxes, which are typically paid by a relatively small minority of wage earners in urban China. A valuable property of the data used is that the information on income from previous years (before the survey) is collected by the respondents recalling past incomes. This is why we are able to use information on personal income for the three-year periods 1993 to 1995 as well as 2000 to 2002 as collected by NBS each year, for almost all pairs in our sample. We present estimates using the longer accounting period together with those for the one-year period in Section 3.

/ Table 1 about here/ 
In Table 1 we report descriptive statistics for the two samples. There is no large difference in means between incomes of sons and daughters, while the mean of mothers' incomes is clearly lower than the mean of fathers' incomes. China's rapid economic growth shows up in mean incomes increasing across samples.

There are seven years between our samples and urban China changed greatly during this period. Due to enterprise reform, work units were put under strong financial pressure, workers were laid off, and employment decreased rapidly. The latter was particularly the case for women approaching the general retirement age of 55. This can potentially affect results on intergenerational income elasticities of mothers across samples. For example, a high income for mothers in 2002 can be deemed to be a considerably stronger signal of high work orientation than a high income for mothers in 1995. Another difference between urban China in 1995 and urban China in 2002 is that the rates of return to education increased (see for example Zhang et al., 2005 and Sicular et al, 2007). This can taken separately be assumed to have increased the intergenerational income elasticity across samples.

\section{Results}

/Table 2 about here/

Ideally, analysts would prefer to use lifelong long-term income as the key regressor. However, due to data limitations, researchers resort to a one-year measure or multiple-year average of income as proxies. On the left side of Table 2 are our baseline estimates with sons and daughters pooled for each of the samples reported. For comparison, the right side shows results obtained from income measured for three years. It is well-known that a one-year 
measure of parental income is more susceptible to measurement error than the three-year average of parental income. In cases where the measurement error is classical, the estimates with three-year average parental income should be higher than those using the one-year parental income, i.e., the attenuation bias will be lessened (Solon, 1992). ${ }^{5}$ We see in Table 2 that estimates derived from income calculated for a three-year period are higher in most but not all cases. Estimates of the intergenerational income elasticity for fathers' incomes on the left side of the table are 0.45 and 0.37 , while when income is computed for a three-year period they are 0.48 and 0.51 . The estimates for mothers' incomes are 0.34 and 0.45 when income is computed for a single year and when incomes are computed for a three-year period, 0.31 and 0.52 .

There are several possible explanations for the higher estimates for the children-mother pairs when a one-year measure is used in 1995. For instance, as Haider and Solon (2006) point out, the relationship between current and lifetime income is not constant across the life cycle. If parental income is measured at ages when the earnings trajectory is sufficiently flat, measurement errors in parental income may lead to amplification rather than attenuation bias in estimates of the intergenerational income elasticity. Here we use the same age category for children and parents in three-year averages and we should therefore find the same pattern when comparing estimates using one-year and three-year averages of parental income for the three samples. However, we find different patterns across years, suggesting that the explanation by Haider and Solon (2006) is not applicable here. One possible reason could be

\footnotetext{
${ }^{5}$ However, Mazumder (2005) argues that if the transitory fluctuations are persistent, the short-period average of parental income still leads to a substantial downward bias in the estimated value. If measurement errors are nonclassical, measurement errors can lead to amplification bias instead of attenuation bias (Haider and Solon, 2006).
} 
that the three-year average of mothers' income for some years contains more measurement error than the one-year average income due to recalling errors. ${ }^{6}$

/Table 3 about here/

Results including variables measuring fathers' as well as mothers' income in the model (see Table 3) indicate that both variables matter for income of offspring. While in the 1995 sample the coefficients are considerably stronger for fathers' income than for mothers' income, this is not the case in the 2002 sample. The increase of the income elasticity of mothers is consistent with an interpretation presented in the previous section that due to restructuring of the Chinese economy, mothers' income can be deemed to be a considerably stronger signal of high work orientation in the latter sample.

/Table 4 about here/

In Table 4 we present estimates of the intergenerational income estimates for sons and daughters separated. We find that the estimates for sons and daughters are in many cases similar. Let us comment on this. Assortative mating, that men and women of similar backgrounds tend to marry, is considered to play an important role in the intergenerational transmission of income for married women (Chadwick and Solon, 2002; Ermisch et al., 2006; Raaum et al., 2007). This is due to the negative cross-elasticity of women's labour supply with respect to her husband's wages. As a consequence, intergenerational income persistency

\footnotetext{
${ }^{6}$ IV method could be adopted to deal with the measurement error of reported current income of parents. However, it is difficult to find valid instrument variables which affect parental permanent income and are uncorrelated with children's income. Instrument variables such as education and occupation tend to produce an upward bias in the estimates, which is regarded as an upper boundary of intergenerational income persistence (Solon, 1992).
} 
would be expected to be lower for married women than for men. Raaum et al. (2007) suggest, however, that women have higher own-wage labour supply elasticities than their husbands, leading to a higher intergenerational income persistency and offsetting the effect of assortative mating. For single women, the assortative mating hypothesis is not applicable when it comes to explaining their intergenerational income persistency. It is expected that single women have higher intergenerational income persistency than their married counterparts due to the absence of the negative effects of assortative mating (Black and Devereux, 2011). Our findings reported in Table 4 suggest that the effects of assortative mating and labour supply responses more or less offset each other. ${ }^{7}$ This result is not surprising since Chinese women are much more active in the labour market than their counterparts in most industrialized countries.

A potentially important issue is that in the baseline estimates we only observe members of the two generations who co-reside. If the co-residing parent/child pairs are systematically different from the residing separately parent-children pairs, the estimates based on the former sample could be biased due to sample selection. The 2002 data provide a unique opportunity to check the existence of such bias since it asks for parental information such as age for each household head and spouse, regardless of whether they are living with their parents. Unfortunately, parental income is not reported for parents of household heads and spouses who do not co-reside with their parents. ${ }^{8}$ We inspected the data and found that children coresiding and not co-residing with parents do not differ significantly in employment status. However, children not living with parents have slightly longer years of schooling than children living with parents, and the difference ( 0.6 years) is statistically significant.

\footnotetext{
${ }^{7} \mathrm{We}$ also estimate intergenerational income persistency for married and single women, separately. There is no clear pattern of differences in the estimates between married and single women.

${ }^{8}$ The 1995 survey does not ask parental information of parents who do not co-reside with household heads and spouses. Although we can also employ the Heckman model for the 1995 datasets, we are unable to limit the age of parents to be between 50 and 60 or even to know if the parents are alive.
} 
To correct for the selectivity bias, we use the 2002 sample and model the determinants of residential arrangement using the Heckman two-stage procedures. Adult children are the unit of analysis. In the first stage, a probit model for co-residency is estimated from the combined sample of adult children co-residing with parents and adult children living alone. Following Francesconi and Nicoletti (2006), we use age, ethnicity, region of residence and local house prices as identifying variables. The estimates reported in Table 5 show that the probability of co-residency generally exhibits a U-shape relationship by age of child. Region of residence has no effect on the living arrangement while ethnic minority is positively correlated with the probability of living with parents. Not surprisingly, the mean house price in the city has a significantly positive effect on the probability of co-residence. These results are broadly consistent with the first-stage estimates in Francesconi and Nicoletti (2006).

/Table 5 about here/

In Table 5 we are able to report estimates on intergenerational income elasticities for children after correcting for co-residence bias and applying a three-year accounting period income measure. There is negative self-selectivity of living with parents for children in urban China, indicated by the significantly negative sign of the inverse Mill's ratio. The results reported in Table 5, which are lower than the OLS estimates reported in Tables 2 and 4, are our preferred estimates for 2002 . They amount to 0.53 for the son/father pair when a three year accounting period is applied and 0.50 for son/mother and 0.45 for daughter/mother. The daughter/father elasticity of 0.37 is lower than the others. We can adjust the 1995 baseline estimates for 
selection bias using results for 2002 reported in Table 4 and those in Table $5 .{ }^{9}$ We arrive at a son/father elasticity of 0.47 (instead of 0.49 as reported in Table 4). The similar adjusted elasticity for daughter/father is 0.40 , while that of son/mother is 0.31 and daughter/mother is 0.25. These are our preferred estimates for 1995. Table 6 summarises our preferred estimates for both years.

/Table 6 about here/

Yet, how robust are our results on intergenerational income elasticities? To investigate this we have followed recent contributions to the literature and have made some sensitivity checks for the 2002 data, the topic of the next section.

\section{Sensitivity analyses}

The first sensitivity analysis is to consider possible age and life cycle biases. We proceed in two different ways. First, we add variables measuring age of the child as well as age squared and also age of parent and age of parent squared to the baseline specification. Results from this augmented specification are reported in Table 7. It turns out that these intergenerational income elasticities are similar to those reported for the preferred estimates reported in Table 5.

/Table 7 about here/

\footnotetext{
${ }^{9}$ The Heckman estimations are not possible to make for the 1995 sample as it does not include parents that do not live together with their parents. Therefore we use the relations between the Heckman corrected estimates and the OLS estimates from the 2002 sample and calculate "adjustment factors" for each pair. Those "adjustment factors" are used to transfer the OLS results for thus assuming that the co-residence biases in 1995 is of the same relative magnitude as those in 2002.
} 
In the second step we relax the age restriction for the first generation and allow parents up to age 70 to be included in the sample. This means increasing the sample size with a number of parents receiving a pension as main income source. The new alternative results are reported in Table 8 and they are rather similar to the preferred ones reported in Table 6 . This is not surprising as the number of parents aged 60 to 70 is not particularly large, and pensions in urban China are rather strongly linked to earnings received during the active period. ${ }^{10}$

/Table 8 about here/

Finally, we address the issue of whether intergenerational income elasticity differs in different parts of the income distribution by estimating quantile equations, in which only the relevant variables of parental income are included as regressors. Figure 2 presents estimates for the base specification as well as confidence intervals. There is little evidence of intergenerational income elasticity varying over the income distribution, particularly among sons.

/Figure 2 about here/

\section{Putting the results in perspective}

As reported in Table 5 we have found that the intergenerational income elasticity of sons to fathers in 2002 is 0.53 and 0.47 for 1995 when an accounting period of three years is applied and corrected for co-residence bias. How do these preferred estimates compare to that reported in the literature? First we compare our estimates for urban China with the two others

\footnotetext{
${ }^{10}$ In an alternative sensitivity analysis we restrict the maternal age to 50 to 55 (resulting in a smaller sample size) to consider if possible selectivity in leaving the labour force affects the results. We found no systematic difference to the baseline estimates.
} 
we are aware of. Our estimate for the son/father pair is higher than the estimate reported by Guo and Min (2008) based on data for 2004. These authors report an intergenerational income elasticity for the child-father pair of 0.32 . However, this is almost identical to the 0.33 which is obtained when a one-year income accounting period is used in the 2002 sample and corrected for selection bias (results now shown in the tables). An elasticity of 0.32 is considerably lower than our preferred estimates of 0.53 for 2002 and 0.47 for 1995 , both of which are based on an income accounting period of three years and adjusted for co-residency bias.

Gong et al (2012) present estimates for urban China based on data for 2004 using various methods. Their preferred estimates are based on permanent income predicted by parental education from IV method, which can be considered as upper bound. From this follows that it is not surprising that in three of four cases are their estimates higher than ours. The exception is their preferred estimate 0.36 for son/mother, which is in the interval of our preferred estimates for 1995 (0.31) and for 2002 (0.50). For daughter/mother their preferred estimate is 0.64, and for son/father is 0.63 . Most different from ours is the preferred estimate of Gong et al (2012) for daughter/father as it is as high as 0.97 while our preferred estimates are 0.40 (1995) and 0.37 (2002)..

How do our estimates compare with those obtained for other countries? As estimates on intergenerational income elasticities can be assumed to depend on the research design, the most satisfactory way to compare them would be to harmonise how samples are drawn, years of observation, key assumptions on age of persons in the two generations and income definition. The most ambitious effort to date in terms of number of countries covered in the literature is probably Jäntti et al (2006). The authors studied pairs of sons and fathers as well 
as daughters and fathers in the four large Nordic countries, the United States and the United Kingdom. The results indicate higher intergenerational income persistency in the United States than in the United Kingdom, higher than in the Nordic countries.

Another strategy for comparing intergenerational income persistency is to base judgements on published results after having considered their appropriateness as well as possibly adjusting results due to research methods. The advantage of this strategy is that the comparison can cover a relatively large number of countries. The disadvantage is that the degree of comparability is lower than in the first strategy mentioned. Corak (2006) and Blanden (2011) have used the second strategy. Blanden's survey lists 24 studies by data source, son's outcome variable, parental income variable and approach to measurement error. Following Corak (2006), it scaled down all elasticities derived by the Instrumental Variable method (which is known to produce upward biased estimates), by the factor 0.75 derived from studies on the United States.

In the upper part of Table 9 we reproduce the preferred estimates of intergenerational income elasticities for son/father pairs by Blanden (2011) for 11 high-income countries. The middle part of the same table shows estimates for five developing countries obtained by Grawe (2004). These estimates are typically obtained from small samples (the smallest being 98 pairs for Peru), and have comparably high standard errors; for this reason we do not put much emphasis on them. In the table we have also included estimates for Brazil, Chile, Japan and Spain reported in the recent literature as well as our preferred estimates for urban China.

/Table 9 about here/ 
The content in Table 9 leads us to draw the following tentative conclusions: Intergenerational income persistency for son/father appears to be higher in urban China than in Australia, Canada, Denmark, Finland, Germany, Norway and Sweden, that is, high income countries with large or relatively large welfare states. How to rank urban China with the remaining other high-income countries is less clear as confidence intervals overlap. Our point estimates of intergenerational income persistency in urban China are higher than the adjusted estimates of Grawe (2004) for Nepal and Pakistan. Among high income countries surveyed by Blanden (2011), only the United Kingdom and the United States have an intergenerational income elasticity similar to what we have reported for urban China. The category of countries with high intergenerational income persistency in Table 9 also includes Brazil, Chile, Ecuador and Peru. $^{11} 12$

We do not expect that the results on intergenerational income persistency reported here necessarily carry over to other birth cohorts in urban China. The research on intergenerational income mobility in rich countries has typically started by analysing people who are born during a short or (as here) relatively short interval. More recent research has investigated how the intergenerational income elasticity varies across cohorts or over time and found signs of change. For Britain, Blanden et al (2004) report a stronger relation of incomes across generations for those born in 1970 than for those born in 1958. Another example is for the US, where Aaronson and Mazumer (2008) find that intergenerational income persistency decreased from 1950 to 1980 , but increased thereafter.

\footnotetext{
${ }^{11}$ Possibly Singapore should also belong to this category. See $\mathrm{Ng}$ et al (2009) who harmonised data for Singapore and the United States, reporting similar elasticities for the two countries.

${ }^{12}$ The cross-country comparison on daughter-parent pairs in the five country study of Raaum et al (2007) show that the elasticities for urban China reported in our study are higher, not only compared to Denmark, Finland and Norway, but also compared to the United Kingdom and the United States.
} 


\section{Conclusions}

In this paper we have estimated intergenerational income elasticities for urban China using samples covering many cities. We have observed people who in 1995 and 2002 were aged 25 to 35 and who co-resided with their parents. We have found that applying a three-year accounting period in most cases leads to higher estimates while correcting estimates for coresidency bias makes the estimates lower. In contrast, including age in the estimated model or varying age restrictions for the sample is of little importance for estimates for the intergenerational income elasticity. There were few indications of variation in the intergenerational income elasticity across the income distribution.

We have found that in urban China in 2002, the income relations between the pairs: son/ father, son/mother and daughter/mother, are all relatively similar in magnitude. We read this as an expression of comparably small gender differences existing in the urban Chinese labour market. In contrast, the relation between daughters' income and fathers' income is weaker. The income relation between offspring and parents became somewhat stronger from 1995 to 2002. Our preferred intergenerational income elasticity for the father/son pairs based on fathers' income measured over a three-year period and correction for co-residency applied, is 0.47 for 1995 and 0.53 for 2002 ; the intergenerational income elasticity for the mother/son pairs is 0.31 and 0.50 in 1995 and 2002, respectively. For the father/daughter pairs, the intergenerational income elasticity is 0.40 in 1995 and 0.33 in 2002. For the mother-daughter pairs, the intergenerational income elasticity is 0.25 in 1995 and 0.45 in 2002. Improvement of data quality, such as the collection of long panel datasets and supplemental datasets with 
income for all parents, even those living separated from their adult children, would produce more accurate estimates of intergenerational income persistency in China.

According to this study, the magnitude of the intergenerational income elasticity for the son/father pairs in urban China is higher than that reported in studies for several high-income countries with large or relatively large welfare states. This category includes Australia, Canada, Denmark, Finland, Germany, Norway and Sweden. From the literature, we are inclined to put urban China in a category of countries having a stronger income link between sons and fathers, a category which also includes countries such as Brazil, Chile and the US. It remains the task of future research to determine to what extent such a categorisation is justified or can be improved. Another task for future study is to analyse reasons why intergenerational income persistency in urban China appears to be comparably high. 


\section{References}

Aaronson, D. and Mazumder, B. (2008) "Intergenerational Economic Mobility in the United States, 1940 to 2000”, Journal of Human Resources, 43, 139 - 172.

Björklund, A. and Cadwick, L. (2003) "Intergenerational Income Mobility in Permanent and Separated Families", Economic Letters, 80, 239-246.

Björklund, A. and Jäntti, M. (1997) 'Intergenerational Income Mobility in Sweden compared to the United States", American Economic Review, 87 (5), 1009 - 1018.

Björklund, A. and Jäntti, M. (2009) "Intergenerational Income Mobility and the Role of Family Background”, in Salverda, W., Nolan, B. and Smeeding, T. (Eds) (2009) The Oxford Handbook of Economic Inequality, Oxford: Oxford University Press.

Black, Sandra E. and Devereux, P. (2011), "Recent Developments in Intergenerational Mobility”, in Handbook of Labor Economics, Volume 4, Part 2, 2011, Pages 1487-1541.

Blanden, J. (2011) “Cross-country Rankings of Intergenerational Mobility: A Comparison of Approaches from Economics and Sociology”, Journal of Economic Surveys. Published online June 23, 2011.

Blanden, J., Goodman, A., Gregg, P., Machin, S. (2004) "Changes in Intergenerational Mobility in Britain" Chapter 6 in Corak, M. (Ed) Generational Income Mobility in North America and Europe, Cambridge: Cambridge University Press. 
Bratsberg, B., Roed, K., Raaum, O., Naylor, R., Jäntti, M., Eriksson, T. and Österbacka, E. (2007) "Nonlinearities in Intergenerational Earnings Mobility. Consequences for Crosscountry comparisons", Economic Journal, 117 (519) C72 - C92.

Chadwick, Laura and Gary Solon, (2002), "Intergenerational Income Mobility among Daughters", American Economic Review, Vol. 92 (1), pp. 335-344.

Chen, Y. and Feng, S. (2009) "Parental Education and Wages: Evidence from China", Institute for the Study of Labor (IZA), Discussion Paper No. 4218.

Corak, M. (2006) "Do Poor Children become Poor Adults? Lessons for Public Policy from a Cross Country Comparison of Generational Earnings Mobility", Research on Economic Inequality, $13,143-188$.

Couch, K. and Lillard, D. (1998) "Sample Selection Rules and the Intergenerational Correlation of Earnings", Labour Economics, 5, 313 - 329.

Croll, E. (2006) China's New Consumers. Social development and domestic demand, London and New York: Routledge.

Dearden, L., Machin, S. and Reed, H. (1997) "Intergenerational Mobility in Britain", Economic Journal, 107, 47-64. 
Dunn, C. (2007) “The Intergenerational Transmission of Lifetime Earnings: Evidence from Brazil”, Berkeley Electronic Journal of Economic Analysis \& Policy, 7 (2), Article 2.

Ermisch, John, Marco Francesconi and Thomas Siedler, 2006, "Intergenerational Mobility and Marital Sorting”, Economic Journal, 116: 659-679.

Fereira, S.G. and Veloso, F. (2006) "Intergenerational Mobility of Wages in Brazil”, Brazilian Review of Econometrics, 26, 2, 181-211.

Francesconi, M. and Nicoletti, C.. (2006), "Intergenerational Mobility and Sample Selection in Short Panels", Journal of Applied Econometrics, 21, 1265-1293.

Gong, C. H. , Leigh, A. and Meng, X. (2012) "Intergenerational Income Mobility in Urban China", Review of Income and Wealth, 58, $481-503$. .

Grawe, N. D. (2004) "Intergenerational Mobility for Whom? The Experience of high- and low-earning sons in international perspective" Chapter 4 in Corak, M. (Ed) Generational Income Mobility in North America and Europe, Cambridge: Cambridge University Press.

Grawe, N. D. (2006) "Life Cycle Estimates of Intergenerational Earnings Persistence", Labour Economics, 13 (5), $551-570$.

Guo, C., Min W. (2008) "Education and Intergenerational Income Mobility in Urban China", Frontiers of Education in China, 3 (1) $22-44$. 
Haider, Steven and Gary Solon, 2006, "Life-Cycle Variation in the Association between Current and Lifetime Earnings", American Economic Review, Vol. 96, No.4, pp. 1308-1320.

Hussein, M. Munk, M and Bonke, J. (2008) "How Sensitive is Intergenerational Earnings Mobility to Different Measures?” Danish National Centre for Social Research, Working Paper 07:2008,

Jäntti, M., Bratsberg, B., Röed, K., Raaum, O., Naylor, R., Österbacka, E., Björklund, A. and Eriksson, T. (2006) "American Exceptionalism in a New Light: A Comparison of Intergenerational Earnings Mobility in the Nordic Countries, the United Kingdom and the United States", Institute for the Study of Labor (IZA) Discussion Paper No. 1938.

Knight, J. and Song, L. (1999) The Rural - Urban Divide. Economic Disparities and Interactions in China, Oxford: Oxford University Press.

Knight, J. and Yueh, L. (2008) "The Role of Social Capital in the Labour Market in China", Economics of Transition, 16 (3), $389-414$.

Lefranc, H. and Trannoy, A. (2005) "Intergenerational Earnings Mobility in France: Is France More Mobile than the US?", Annales d'Economie et de Statistique, 78, 57-77.

Leigh, A. (2007) "Intergenerational Mobility in Australia", Berkeley Electronic Journal of Economic Analysis and Policy, 7 (2) Article 6. 
Li, S., Luo, C., Wei, Z and Yue, X. (2008) "The 1995 and 2002 Household Surveys: Sampling Methods and Data Description", in Gustafsson, B., Li, S. and Sicular, T. (Eds) Inequality and Public Policy in China, Cambridge: Cambridge University Press.

Mazumder, B. (2005), "Fortunate Sons: New Estimates of Intergenerational Mobility in the U.S. Using Social Security Earnings Data", Review of Economics and Statistics, vol. 87 (2), 235-55.

Mocetti, S. (2007) “Intergenerational Earnings Mobility in Italy”, Berkeley Electronic Journal of Economic Analysis \& Policy, 7 (2), Article 5.

Ng, I., Shen, X and Ho, K.W. (2009) "Intergenerational Earnings Mobility in Singapore and the United States", Journal of Asian Economics, 20, 110-119.

Nicoletti, C. and Ermish, J. (2007) "Intergenerational Earnings Mobility: Changes Across Cohorts in Britain", Berkeley Electronic Journal of Economic Analysis \& Policy, 7 (2), Article 9.

Nunez, J. and Miranda, L. (2010) "Intergenerational Income Mobility in a Less-Developed, High-Inequality Context: The Cases of Chile", Berkeley Electronic Journal of Economic Analysis \& Policy, 10 (1), Article 33.

Nielsen, O, Vaage, K., Artvik, A. and Jacobsen, K. (2008) "Estimates of Intergenerational Elasticities Based on Lifetime Earnings", Institute for the Study of Labor (IZA), Discussion Paper No 3709. 
Österbacka, E. (2001) "Family Background and Economic Status in Finland”, Scandinavian Journal of Economics, 103, 3, 467-84.

Pascual, M. (2009) "Intergenerational Income Mobility: The Transmission of SocioEconomic Status in Spain”, Journal of Policy Modeling, 31, 835-846.

Pekkarienen et al (2009) "School Tracking and Intergenerational Income Mobility: Evidence from the Finnish Comprehensive School Reform", Journal of Public Economics, 93, 965-973.

Pirano, P. (2007) “Comparable Estimates of Intergenerational Income Mobility in Italy", Berkeley Electronic Journal of Economic Analysis \& Policy, 7 (2), Article 1.

Raaum, O., Bratsberg, B., Roed, K., Österbacka, E., Eriksson, T., Jäntti, M. and Naylor, R. (2007) "Marital Sorting, Household Labor Supply, and Intergenerational Earnings Mobility across Countries", Berkeley Electronic Journal of Economic Analysis and Policy, 7 (2) 1 Article 7.

Roemer, J. E. (2004) "Equal Oportunities and Intergenerational Mobility: Going Beyond Intergenerational Transition Matrices" Chapter 3 in Corak, M. (Ed) Generational Income Mobility in North America and Europe, Cambridge: Cambridge University Press.

Sicular, T., Yue, X., Gustafsson, B and Li, S. (2007) "The Urban-Rural Income Gap and Inequality in China" Review of Income and Wealth, 53, 93 - 126. 
Solon, G. (1992) "Intergenerational Income Mobility in the United States", American Economic Review, 82 (3) 393 - 408.

Solon, G. (2002) “Cross-Country Differences in Intergenerational Earnings Mobility”, Journal of Economic Perspectives, 16(3): $59-66$.

Solon, G. (2004) “A Model for Intergenerational Mobility Variation Over Time and Place”, Chapter 2 in Corak, M. (Ed) Generational Income Mobility in North America and Europe, Cambridge: Cambridge University Press.

Ueda, A. (2009) "Intergenerational Mobility of Earnings and Income in Japan", Berkeley Electronic Journal of Economic Analysis \& Policy, 9 (1), Article 54.

Vogel, T. (2008) "Reassessing Intergenerational Mobility in Germany and the United States: The Impact of Different Lifecycle Earnings Patterns", SFB 649 Humboldt-Universität zu Berlin, Discussion Paper 2006-055,

Zimmerman, D. J. (1992) "Regression Toward Mediocrity in Economic Stature", American Economic Review, 82 (2) 409 - 429.

Zhang, Junsen, Zhao, Yaohui, Albert Park, and Song Xiaoqing, (2005), "Economic returns to schooling in urban China, 1988 to 2001," Journal of Comparative Economics, 33, 730-752. 
Figure 1. The probability for children to co-reside with parents by age, urban China 2002

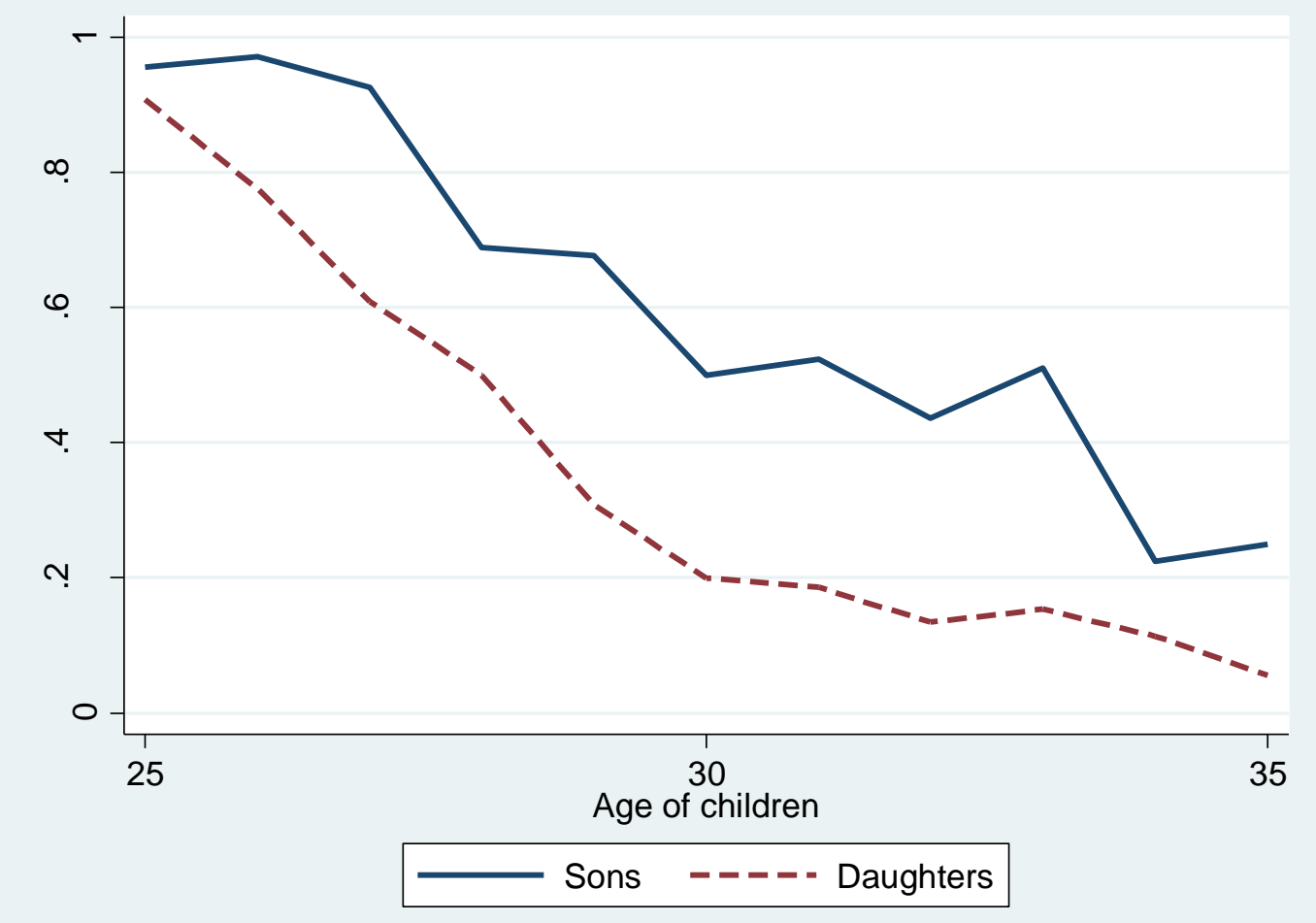

Source: Authors' calculations from CHIP data 2002, urban sample. 


\section{Figure 2}

Estimates of intergenerational income elasticities derived from quantile regressions. Baseline specification for year 2002.

The shaded area indicates a 95-percent confidence interval.

\section{Sons vs. fathers}

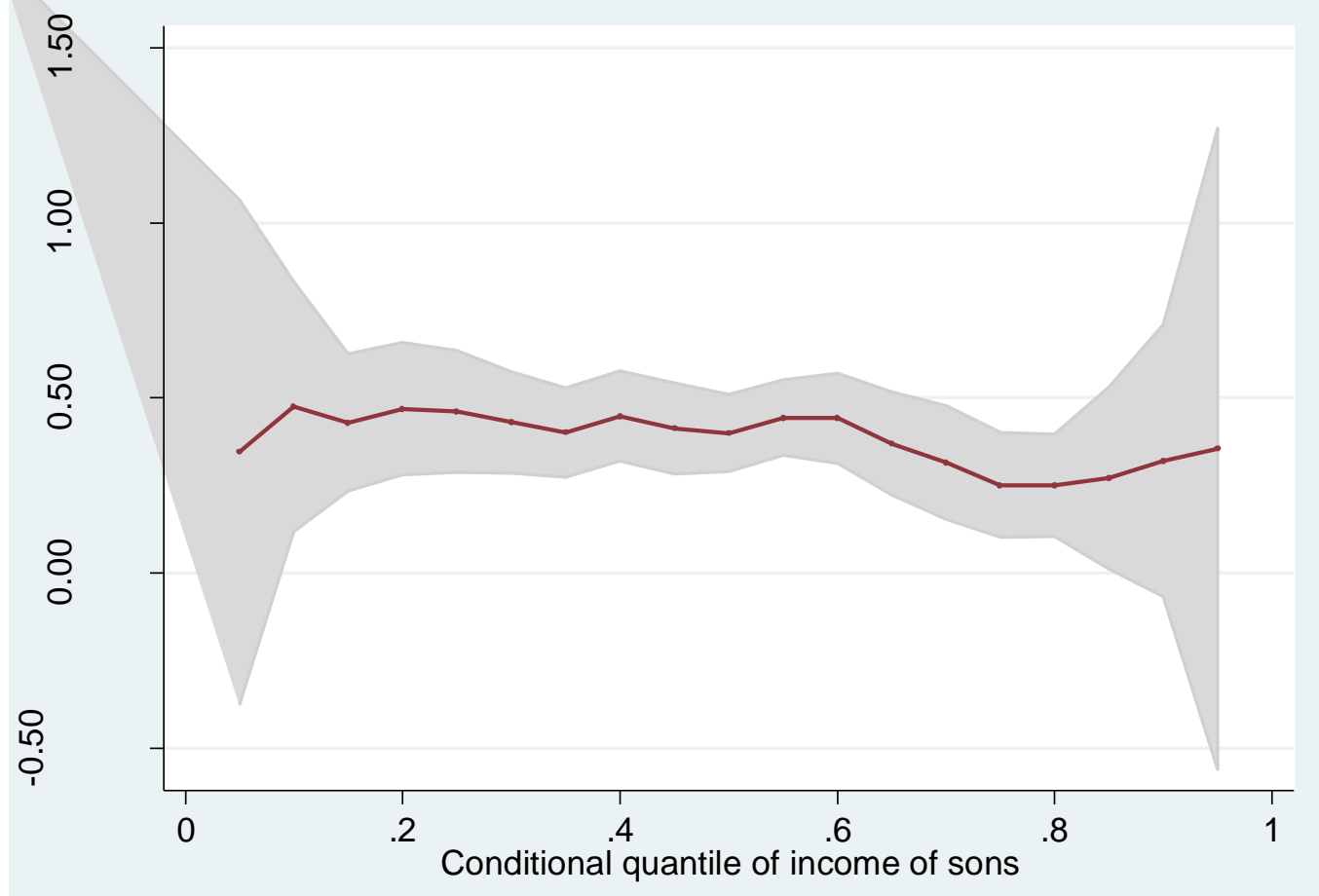


Sons vs. mothers

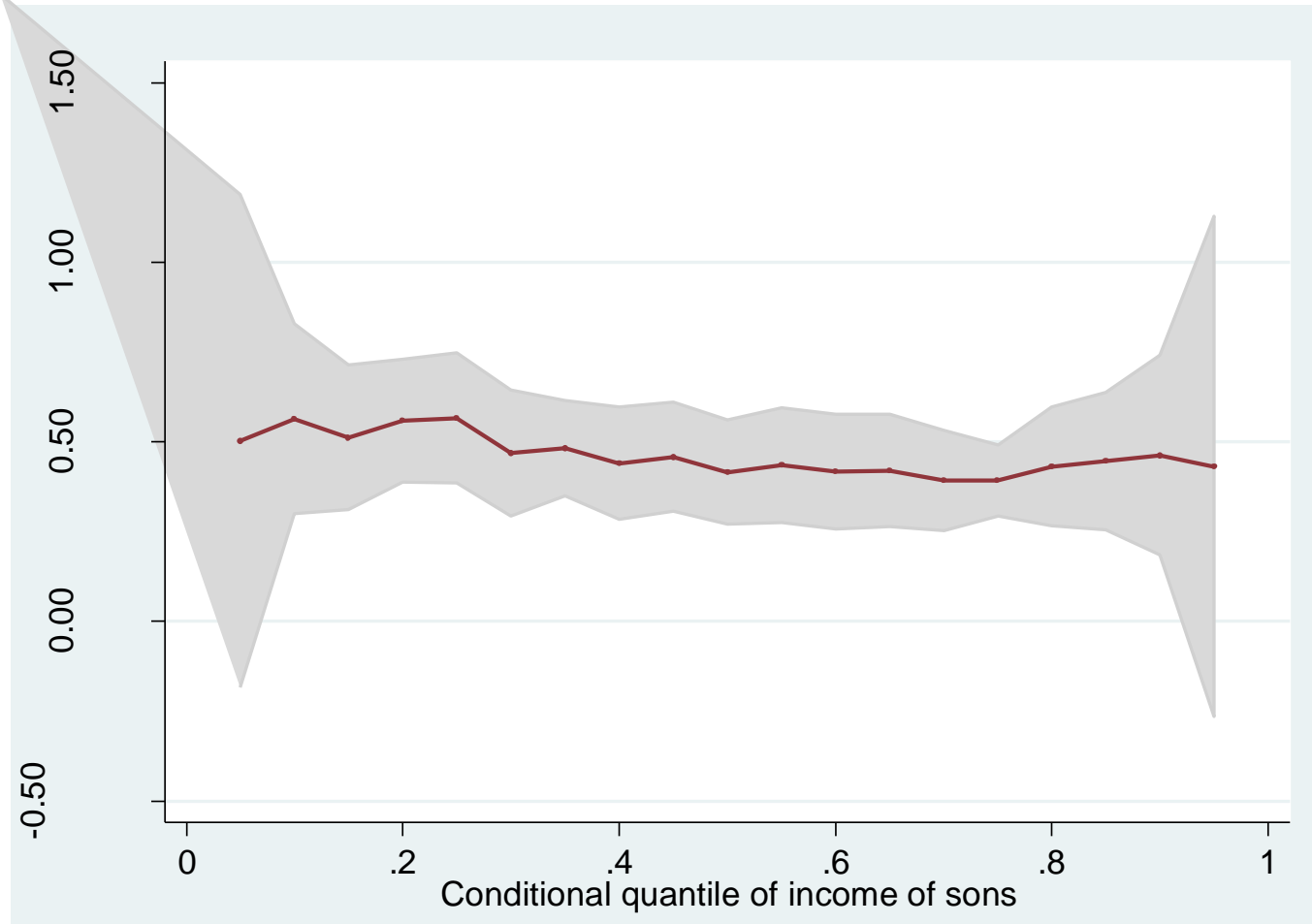

\section{Daughters vs. fathers}

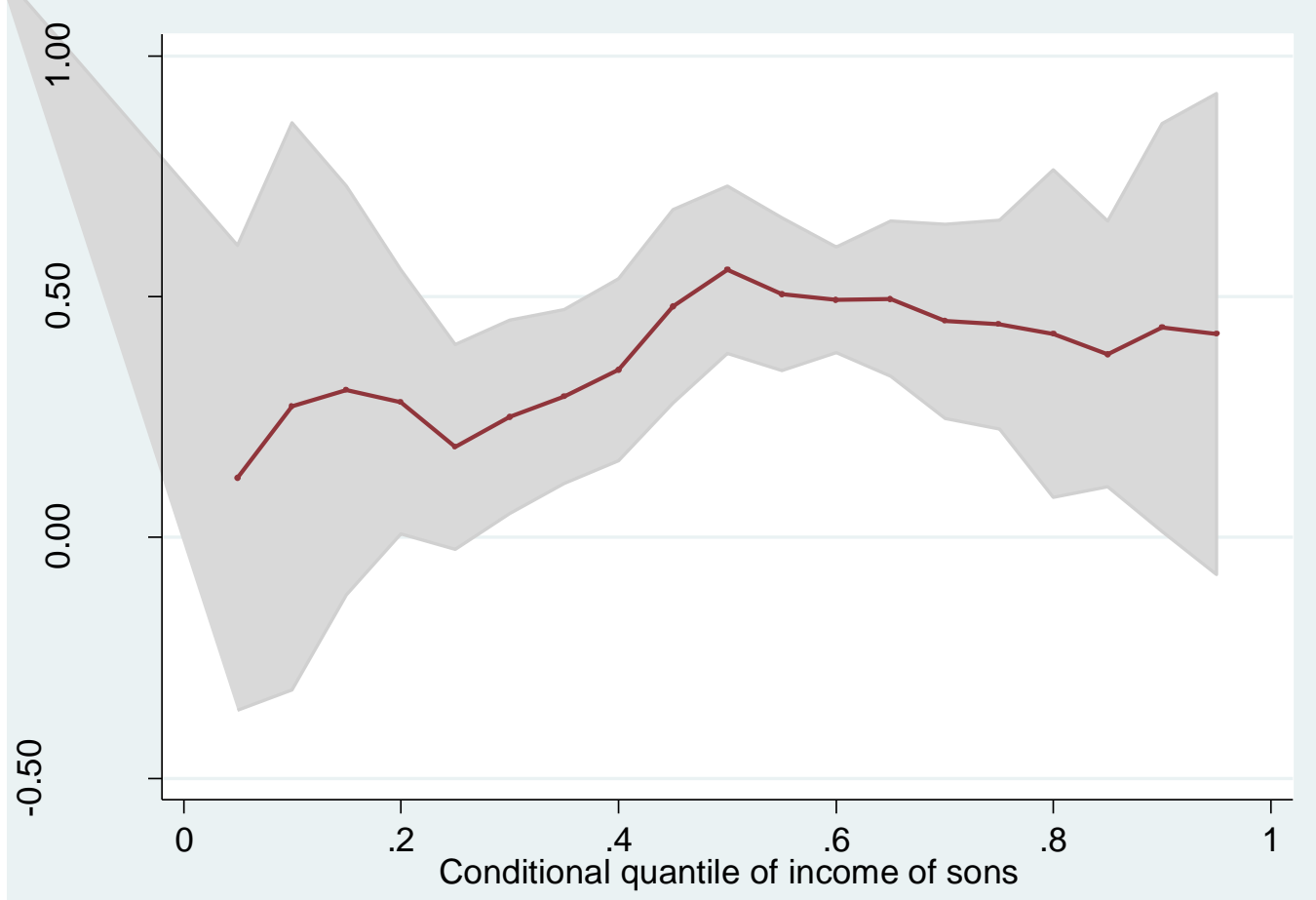


Daughters vs. mothers

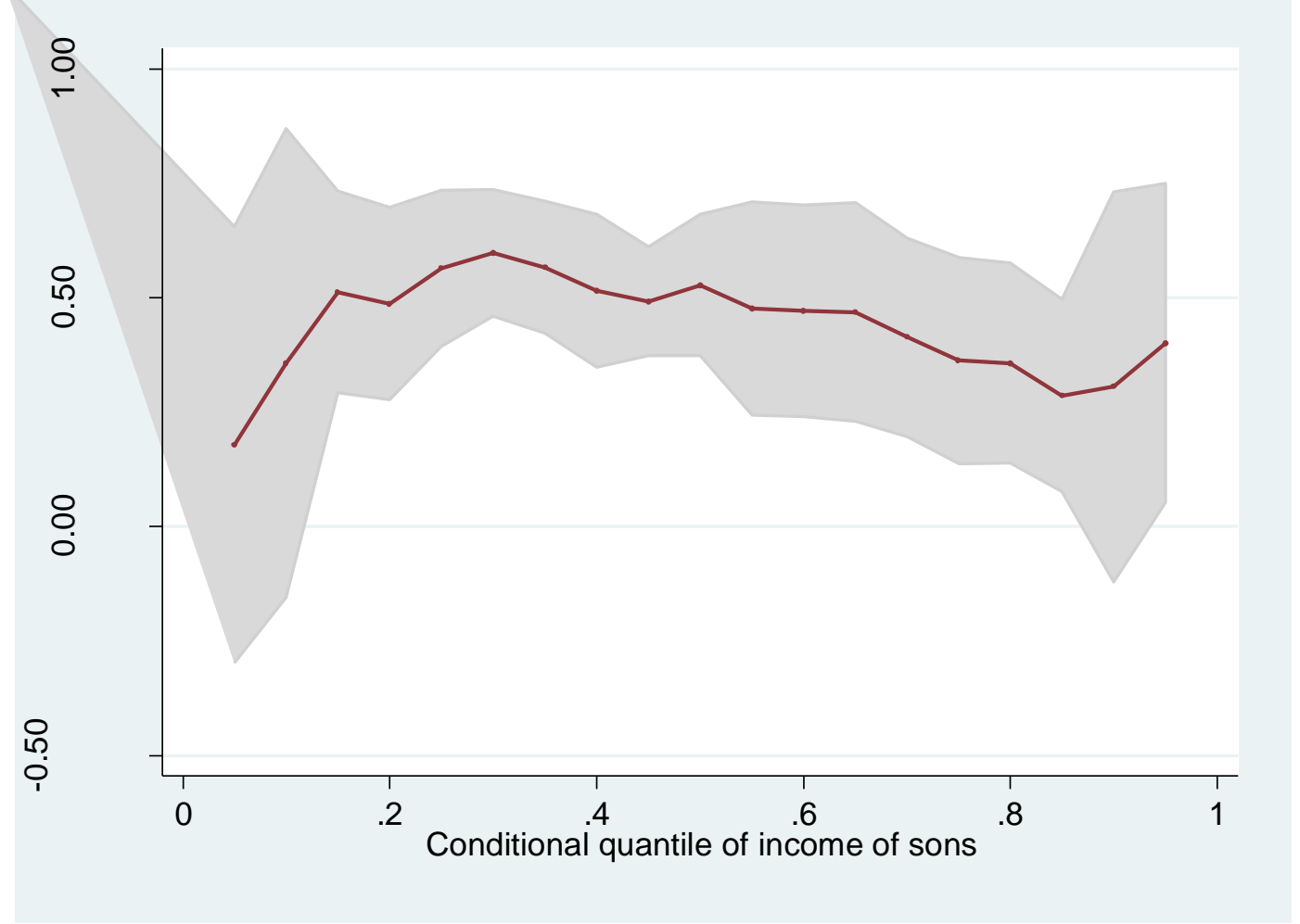


Table 1 Descriptive statistics.

\begin{tabular}{|c|c|c|c|}
\hline Variable & $\begin{array}{l}\text { Number of } \\
\text { observations }\end{array}$ & Mean value & $\begin{array}{l}\text { Standard } \\
\text { Deviation }\end{array}$ \\
\hline \multicolumn{4}{|l|}{1995} \\
\hline Son's age & 381 & 27.72 & 2.70 \\
\hline Daughter's age & 176 & 27.20 & 2.46 \\
\hline Father's age & 377 & 56.03 & 2.97 \\
\hline Mother's age & 429 & 55.06 & 2.97 \\
\hline Son's income & 381 & 6011.07 & 5599.47 \\
\hline Daughter's income & 176 & 5268.23 & 3701.66 \\
\hline Father's income & 377 & 8640.69 & 4835.39 \\
\hline Mother's income & 429 & 5833.38 & 3805.68 \\
\hline $\begin{array}{l}\text { 3-year average of } \\
\text { father's income }\end{array}$ & 350 & 8226.45 & 4498.17 \\
\hline $\begin{array}{l}\text { 3-year average of } \\
\text { mother's income }\end{array}$ & 387 & 5693.14 & 3049.05 \\
\hline \multicolumn{4}{|l|}{2002} \\
\hline Son's age & 415 & 28.39 & 2.78 \\
\hline Daughter's age & 240 & 27.28 & 2.45 \\
\hline Father's age & 481 & 55.66 & 2.54 \\
\hline Mother's age & 570 & 54.36 & 2.82 \\
\hline Son's income & 415 & 10957.83 & 11795.67 \\
\hline Daughter's income & 240 & 9801.82 & 7969.08 \\
\hline Father's income & 481 & 12717.30 & 9324.33 \\
\hline Mother's income & 570 & 9136.49 & 5919.76 \\
\hline $\begin{array}{l}\text { 3-year average of } \\
\text { father's income }\end{array}$ & 473 & 11780.84 & 7414.32 \\
\hline $\begin{array}{l}\text { 3-year average of } \\
\text { mother's income }\end{array}$ & 559 & 8473.21 & 5312.75 \\
\hline
\end{tabular}

Note: All incomes are in 2002 prices (Yuan).

Source: CHIP data for 1995 and 2002. 
Table 2. Intergenerational income elasticity for children aged 25-35 and their coresiding parents aged 50-60. Baseline estimates of one equation model.

\begin{tabular}{|c|c|c|c|c|}
\hline \multirow{2}{*}{$\begin{array}{l}\text { Income } \\
\text { accounting } \\
\text { period } \\
\text { Sample }\end{array}$} & \multicolumn{2}{|c|}{$\begin{array}{l}\text { One-year accounting } \\
\text { period }\end{array}$} & \multicolumn{2}{|c|}{$\begin{array}{l}\text { Three-year accounting } \\
\text { period }\end{array}$} \\
\hline & $\begin{array}{l}\text { Sons and } \\
\text { Daughters }\end{array}$ & $\begin{array}{l}\text { Sons and } \\
\text { Daughters }\end{array}$ & $\begin{array}{c}\text { Sons and } \\
\text { Daughters }\end{array}$ & $\begin{array}{l}\text { Sons and } \\
\text { Daughters }\end{array}$ \\
\hline $\begin{array}{l}\mathbf{1 9 9 5} \\
\text { Father's } \\
\text { income }\end{array}$ & $\begin{array}{c}0.453 * * * \\
(0.068)\end{array}$ & & $\begin{array}{c}0.477 * * * \\
(0.072)\end{array}$ & \\
\hline $\begin{array}{l}\text { Mother's } \\
\text { income }\end{array}$ & & $\begin{array}{c}0.340 * * * \\
(0.054)\end{array}$ & & $\begin{array}{c}0.308 * * * \\
(0.066)\end{array}$ \\
\hline Constant & $\begin{array}{c}4.231 * * * \\
(0.598)\end{array}$ & $\begin{array}{c}5.460 * * * \\
(0.456)\end{array}$ & $\begin{array}{c}4.008 * * * \\
(0.639)\end{array}$ & $\begin{array}{c}5.718 * * * \\
(0.554)\end{array}$ \\
\hline $\begin{array}{l}\text { Adj. } \mathrm{R}^{2} \\
\text { Observations }\end{array}$ & $\begin{array}{c}0.1042 \\
377\end{array}$ & $\begin{array}{c}0.0817 \\
429\end{array}$ & $\begin{array}{c}0.1082 \\
350\end{array}$ & $\begin{array}{c}0.0512 \\
387\end{array}$ \\
\hline $\begin{array}{l}\mathbf{2 0 0 2} \\
\text { Father's } \\
\text { income }\end{array}$ & $\begin{array}{c}0.370 * * * \\
(0.053)\end{array}$ & & $\begin{array}{c}0.508 * * * \\
(0.062)\end{array}$ & \\
\hline $\begin{array}{l}\text { Mother's } \\
\text { income }\end{array}$ & & $\begin{array}{c}0.448 * * * \\
(0.053)\end{array}$ & & $\begin{array}{c}0.520 * * * \\
(0.064)\end{array}$ \\
\hline Constant & $\begin{array}{c}5.546 * * * \\
(0.491)\end{array}$ & $\begin{array}{c}4.965 * * * \\
(0.476)\end{array}$ & $\begin{array}{c}4.292 * * * \\
(0.568)\end{array}$ & $\begin{array}{c}4.353 * * * \\
(0.567)\end{array}$ \\
\hline $\begin{array}{l}\text { Adj. } \mathrm{R}^{2} \\
\text { Observations }\end{array}$ & $\begin{array}{c}0.0905 \\
481\end{array}$ & $\begin{array}{c}0.11 \\
570\end{array}$ & $\begin{array}{c}0.1244 \\
473\end{array}$ & $\begin{array}{c}0.1057 \\
559\end{array}$ \\
\hline
\end{tabular}

Source: Authors' estimates from CHIP data for 1995 and 2002. 
Table 3. Estimates of intergenerational income elasticity for children aged 25-35 and their co-residing parents aged 50-60 1995 and 2002. Baseline estimates of two variable model.

\begin{tabular}{|c|c|c|}
\hline \multirow{3}{*}{$\begin{array}{l}\text { Income accounting } \\
\text { period }\end{array}$} & \multirow{3}{*}{$\begin{array}{l}\text { One year } \\
\text { Sons and } \\
\text { Daughters }\end{array}$} & \multirow{3}{*}{$\begin{array}{c}\text { Three years } \\
\text { Sons and } \\
\text { Daughters }\end{array}$} \\
\hline & & \\
\hline & & \\
\hline \multicolumn{3}{|l|}{1995} \\
\hline Father's income & $\begin{array}{c}0.454 * * * \\
(0.078)\end{array}$ & $\begin{array}{c}0.455^{* * *} * \\
(0.089)\end{array}$ \\
\hline Mother's income & $\begin{array}{c}0.169 * * \\
(0.067)\end{array}$ & $\begin{array}{c}0.166^{*} \\
(0.090)\end{array}$ \\
\hline Constant & $\begin{array}{c}2.833 * * * \\
(0.700)\end{array}$ & $\begin{array}{l}2.819 * * * \\
(0.782)\end{array}$ \\
\hline Adj. $\mathrm{R}^{2}$ & 0.1538 & 0.1446 \\
\hline Observations & 325 & 289 \\
\hline \multicolumn{3}{|l|}{2002} \\
\hline Father's income & $\begin{array}{c}0.263 * * * \\
(0.056)\end{array}$ & $\begin{array}{c}0.391 * * * \\
(0.068)\end{array}$ \\
\hline Mother's income & $\begin{array}{c}0.403 * * * \\
(0.069)\end{array}$ & $\begin{array}{c}0.352 * * * \\
(0.076)\end{array}$ \\
\hline Constant & $\begin{array}{l}2.956 * * * \\
(0.677)\end{array}$ & $\begin{array}{l}2.268 * * * \\
(0.736)\end{array}$ \\
\hline Adj. $\mathrm{R}^{2}$ & 0.1545 & 0.167 \\
\hline Observations & 427 & 416 \\
\hline
\end{tabular}

Source: Authors' estimates from CHIP data for 1995 and 2002. 
Table 4 Estimates of intergenerational income elasticity for sons and daughters aged 2535 and their co-residing parents aged 50-60, 1995 and 2002. Baseline estimates of one variable model.

\begin{tabular}{|c|c|c|c|c|c|c|c|c|}
\hline & \multicolumn{4}{|c|}{ One-year accounting period } & \multicolumn{4}{|c|}{ Three-year accounting period } \\
\hline & Sons & Daughters & Sons & Daughters & Sons & Daughters & Sons & Daughters \\
\hline \multirow{3}{*}{$\begin{array}{l}1995 \\
\text { Father's } \\
\text { income }\end{array}$} & & & & & & & & \\
\hline & $0.474 * * *$ & $0.430 * * *$ & & & $0.491 * * *$ & $0.482 * * *$ & & \\
\hline & $(0.079)$ & $(0.126)$ & & & $(0.083)$ & $(0.141)$ & & \\
\hline $\begin{array}{l}\text { Mother's } \\
\text { income }\end{array}$ & & & $0.302 * * *$ & $0.417 * * *$ & & & $0.325 * * *$ & $0.282 * *$ \\
\hline & & & $(0.064)$ & $(0.100)$ & & & $(0.078)$ & $(0.119)$ \\
\hline Constant & $\begin{array}{c}4.090 * * * \\
(0.699)\end{array}$ & $\begin{array}{c}4.334 * * * \\
(1.122)\end{array}$ & $\begin{array}{c}5.850 * * * \\
(0.535)\end{array}$ & $\begin{array}{c}4.661 * * * \\
(0.840)\end{array}$ & $\begin{array}{c}3.943 * * * \\
(0.731)\end{array}$ & $\begin{array}{c}3.834 * * * \\
(1.254)\end{array}$ & $\begin{array}{c}5.642 * * * \\
(0.655)\end{array}$ & $\begin{array}{c}5.781 * * * \\
(1.002)\end{array}$ \\
\hline Adj. $R^{2}$ & 0.1186 & 0.0829 & 0.0681 & 0.1091 & 0.1223 & 0.092 & 0.059 & 0.0363 \\
\hline Observations & 259 & 118 & 294 & 135 & 244 & 106 & 263 & 124 \\
\hline \multicolumn{9}{|l|}{2002} \\
\hline $\begin{array}{l}\text { Father's } \\
\text { income }\end{array}$ & $0.369 * * *$ & $0.385 * * *$ & & & $0.561 * * *$ & $0.437 * * *$ & & \\
\hline & $(0.066)$ & $(0.090)$ & & & $(0.081)$ & $(0.094)$ & & \\
\hline $\begin{array}{l}\text { Mother's } \\
\text { income }\end{array}$ & & & $0.451 * * *$ & $0.445^{* * *}$ & & & $0.527 * * *$ & $0.508 * * *$ \\
\hline Constant & $\begin{array}{c}5.617 * * * \\
(0.607)\end{array}$ & $\begin{array}{c}5.313 * * * \\
(0.832)\end{array}$ & $\begin{array}{c}(0.070) \\
4.967 * * * \\
(0.626)\end{array}$ & $\begin{array}{c}(0.082) \\
4.936 * * * \\
(0.733)\end{array}$ & $\begin{array}{c}3.845 * * * \\
(0.750)\end{array}$ & $\begin{array}{c}4.867 * * * \\
(0.867)\end{array}$ & $\begin{array}{c}(0.085) \\
4.314 * * * \\
(0.758)\end{array}$ & $\begin{array}{c}(0.096) \\
4.417 * * * \\
(0.853)\end{array}$ \\
\hline Adj. $R^{2}$ & 0.0924 & 0.089 & 0.1007 & 0.1232 & 0.1371 & 0.1043 & 0.0957 & 0.118 \\
\hline Observations & 301 & 180 & 364 & 206 & 295 & 178 & 355 & 204 \\
\hline
\end{tabular}

Source: Authors' estimates from CHIP data for 1995 and 2002. 
Table 5. Intergenerational income elasticity with co-residence bias corrected for. The 2002 sample

\begin{tabular}{|c|c|c|c|c|c|c|}
\hline \multicolumn{7}{|l|}{ Second Stage: } \\
\hline Income of children & Sons and & Daughters & So & & Daug & aters \\
\hline Father's income & $\begin{array}{c}0.467 * * * \\
(0.062)\end{array}$ & & $\begin{array}{c}0.534 * * * \\
(0.082)\end{array}$ & & $\begin{array}{c}0.366 * * * \\
(0.092)\end{array}$ & \\
\hline Mother's income & & $\begin{array}{c}0.476 * * * \\
(0.063)\end{array}$ & & $\begin{array}{c}0.499 * * * \\
(0.085)\end{array}$ & & $\begin{array}{c}0.448 * * * \\
(0.094)\end{array}$ \\
\hline Intercept & $\begin{array}{l}4.813 * * * \\
(0.580)\end{array}$ & $\begin{array}{l}4.922 * * * \\
(0.571)\end{array}$ & $\begin{array}{l}4.182 * * * \\
(0.766)\end{array}$ & $\begin{array}{c}4.678 * * * \\
(0.763)\end{array}$ & $\begin{array}{c}5.782 * * * \\
(0.862)\end{array}$ & $\begin{array}{l}5.207 * * * \\
(0.850)\end{array}$ \\
\hline Inverse Mill's ratio & $\begin{array}{c}-0.267 * * * \\
(0.077)\end{array}$ & $\begin{array}{c}-0.273 * * * \\
(0.065)\end{array}$ & $\begin{array}{l}-0.201 * \\
(0.108)\end{array}$ & $\begin{array}{c}-0.228 * * \\
(0.091)\end{array}$ & $\begin{array}{c}-0.429 * * * \\
(0.113)\end{array}$ & $\begin{array}{c}-0.330 * * * \\
(0.091)\end{array}$ \\
\hline $\begin{array}{l}\text { First stage: } \\
\text { Living } \\
\text { parents }\end{array}$ & & & & & & \\
\hline Children's age & $\begin{array}{c}-1.199 * * * \\
(0.377)\end{array}$ & $\begin{array}{c}-1.739 * * * \\
(0.309)\end{array}$ & $\begin{array}{l}-1.030 * \\
(0.537)\end{array}$ & $\begin{array}{c}-1.968 * * * \\
(0.481)\end{array}$ & $\begin{array}{l}-1.283 * \\
(0.660)\end{array}$ & $\begin{array}{c}-1.977 * * * \\
(0.460)\end{array}$ \\
\hline $\begin{array}{l}\text { Children's age } \\
\text { squared }\end{array}$ & $\begin{array}{l}0.015 * * \\
(0.006)\end{array}$ & $\begin{array}{c}0.025 * * * \\
(0.005)\end{array}$ & $\begin{array}{c}0.012 \\
(0.009)\end{array}$ & $\begin{array}{c}0.028 * * * \\
(0.008)\end{array}$ & $\begin{array}{c}0.015 \\
(0.011)\end{array}$ & $\begin{array}{c}0.028 * * * \\
(0.008)\end{array}$ \\
\hline Minority & $\begin{array}{c}0.028 \\
(0.225)\end{array}$ & $\begin{array}{c}0.458 * * \\
(0.200)\end{array}$ & $\begin{array}{l}-0.027 \\
(0.312)\end{array}$ & $\begin{array}{l}0.542^{*} \\
(0.290)\end{array}$ & $\begin{array}{l}-0.022 \\
(0.351)\end{array}$ & $\begin{array}{c}0.336 \\
(0.299)\end{array}$ \\
\hline $\begin{array}{l}\text { Proportion of } \\
\text { children living with } \\
\text { parents in the local } \\
\text { city }\end{array}$ & $(0.482)$ & $3.195 * * *$ & $3.031 * * *$ & $3.511 * * *$ & $3.196 * * *$ & $(0.691)$ \\
\hline \multicolumn{7}{|l|}{$\begin{array}{l}\text { Region of residence } \\
\text { Eastern China }\end{array}$} \\
\hline Middle China & $\begin{array}{c}-0.448 * * * \\
(0.109)\end{array}$ & $\begin{array}{c}-0.533 * * * \\
(0.093)\end{array}$ & $\begin{array}{l}-0.273 * \\
(0.155)\end{array}$ & $\begin{array}{c}-0.492 * * * \\
(0.132)\end{array}$ & $\begin{array}{c}-0.541 * * * \\
(0.172)\end{array}$ & $\begin{array}{c}-0.512 * * * \\
(0.143)\end{array}$ \\
\hline Western China & $\begin{array}{c}-0.395^{* * * *} \\
(0.124)\end{array}$ & $\begin{array}{c}-0.487 * * * \\
(0.105)\end{array}$ & $\begin{array}{c}-0.427 * * \\
(0.176)\end{array}$ & $\begin{array}{c}-0.481 * * * \\
(0.153)\end{array}$ & $\begin{array}{l}-0.301 \\
(0.189)\end{array}$ & $\begin{array}{c}-0.393 * * \\
(0.156)\end{array}$ \\
\hline Constant & $\begin{array}{l}24.888 * * * \\
(5.540)\end{array}$ & $\begin{array}{c}32.672 * * * \\
(4.636)\end{array}$ & $\begin{array}{l}22.884 * * * \\
(8.011)\end{array}$ & $\begin{array}{l}37.223 * * * \\
(7.329)\end{array}$ & $\begin{array}{c}26.471 * * * \\
(9.511)\end{array}$ & $\begin{array}{c}35.721 * * * \\
(6.821)\end{array}$ \\
\hline Censored obs. & 575 & 834 & 227 & 318 & 348 & 516 \\
\hline Uncensored obs. & 473 & 561 & 295 & 256 & 178 & 205 \\
\hline Observations & 1048 & 1395 & 522 & 674 & 526 & 721 \\
\hline
\end{tabular}

Source: Authors' estimates from the 2002 CHIP data.

Note: The dependent variable in the first stage takes the value of 1 if the adult child is co-residing with parents, otherwise it takes the value of zero.

Children aged 25-35 and their co-residing parents aged 50-60. Three-year average of income of parents is used. 
Table 6. Lists of our preferred estimates

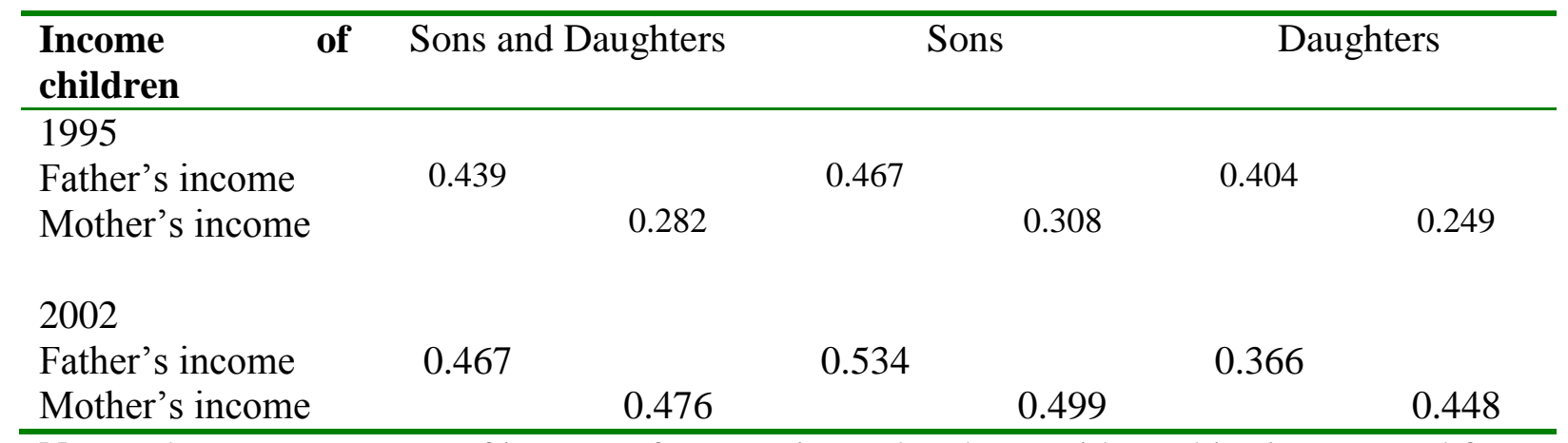

Note: Three-year average of income of parents is used and co-residence bias is corrected for 
Table 7. Intergenerational income elasticity with co-residence bias corrected for, with children' and parental age included in the second stage regression. The 2002 sample

\begin{tabular}{|c|c|c|c|c|c|c|}
\hline \multicolumn{7}{|l|}{ Second Stage: } \\
\hline Income of children & Sons and & Daughters & $\mathrm{Sc}$ & & Daug & hters \\
\hline Father's income & $\begin{array}{c}0.433 * * * \\
(0.063)\end{array}$ & & $\begin{array}{c}0.514 * * * \\
(0.084)\end{array}$ & & $\begin{array}{c}0.325^{* * * *} \\
(0.100)\end{array}$ & \\
\hline Mother's income & & $\begin{array}{c}0.461 * * * \\
(0.067)\end{array}$ & & $\begin{array}{c}0.544 * * * \\
(0.088)\end{array}$ & & $\begin{array}{c}0.331 * * * \\
(0.119)\end{array}$ \\
\hline Children's age & $\begin{array}{l}-0.638^{*} \\
(0.351)\end{array}$ & $\begin{array}{l}-0.252 \\
(0.296)\end{array}$ & $\begin{array}{l}-0.710^{*} \\
(0.427)\end{array}$ & $\begin{array}{l}-0.108 \\
(0.348)\end{array}$ & $\begin{array}{l}-0.600 \\
(0.764)\end{array}$ & $\begin{array}{l}-0.715 \\
(0.648)\end{array}$ \\
\hline $\begin{array}{l}\text { Children's age } \\
\text { squared }\end{array}$ & $\begin{array}{l}0.013 * * \\
(0.006)\end{array}$ & $\begin{array}{c}0.006 \\
(0.005)\end{array}$ & $\begin{array}{l}0.013^{*} \\
(0.008)\end{array}$ & $\begin{array}{c}0.003 \\
(0.006)\end{array}$ & $\begin{array}{c}0.014 \\
(0.014)\end{array}$ & $\begin{array}{c}0.017 \\
(0.011)\end{array}$ \\
\hline Parental age & $\begin{array}{c}0.350 \\
(0.583)\end{array}$ & $\begin{array}{c}0.089 \\
(0.175)\end{array}$ & $\begin{array}{c}0.353 \\
(0.769)\end{array}$ & $\begin{array}{c}0.111 \\
(0.230)\end{array}$ & $\begin{array}{l}-0.110 \\
(0.944)\end{array}$ & $\begin{array}{c}0.174 \\
(0.322)\end{array}$ \\
\hline $\begin{array}{l}\text { Parental age } \\
\text { squared }\end{array}$ & $\begin{array}{l}-0.003 \\
(0.005)\end{array}$ & $\begin{array}{l}-0.001 \\
(0.001)\end{array}$ & $\begin{array}{l}-0.003 \\
(0.007)\end{array}$ & $\begin{array}{l}-0.001 \\
(0.002)\end{array}$ & $\begin{array}{c}0.001 \\
(0.008)\end{array}$ & $\begin{array}{l}-0.002 \\
(0.003)\end{array}$ \\
\hline Intercept & $\begin{array}{c}2.944 \\
(16.166)\end{array}$ & $\begin{array}{c}4.953 \\
(6.205)\end{array}$ & $\begin{array}{c}3.264 \\
(20.813)\end{array}$ & $\begin{array}{c}1.995 \\
(7.691)\end{array}$ & $\begin{array}{c}15.757 \\
(28.618)\end{array}$ & $\begin{array}{c}9.031 \\
(12.696)\end{array}$ \\
\hline Inverse Mill's ratio & $\begin{array}{c}-0.779 * * * \\
(0.190)\end{array}$ & $\begin{array}{c}-0.724 * * * \\
(0.150)\end{array}$ & $\begin{array}{l}-0.539 * \\
(0.281)\end{array}$ & $\begin{array}{c}-0.431 * * \\
(0.196)\end{array}$ & $\begin{array}{c}-1.112 * * * \\
(0.315)\end{array}$ & $\begin{array}{c}-1.252 * * * \\
(0.319)\end{array}$ \\
\hline $\begin{array}{l}\text { First stage: } \\
\text { Living } \\
\text { parents }\end{array}$ & & & & & & \\
\hline Children's age & $\begin{array}{c}-1.199 * * * \\
(0.377)\end{array}$ & $\begin{array}{c}-1.643 * * * \\
(0.321)\end{array}$ & $\begin{array}{l}-1.030 * \\
(0.537)\end{array}$ & $\begin{array}{c}-1.896 * * * \\
(0.494)\end{array}$ & $\begin{array}{l}-1.283^{*} \\
(0.660)\end{array}$ & $\begin{array}{c}-1.795 * * * \\
(0.492)\end{array}$ \\
\hline $\begin{array}{l}\text { Children's age } \\
\text { squared }\end{array}$ & $\begin{array}{c}0.015 * * \\
(0.006)\end{array}$ & $\begin{array}{c}0.023 * * * \\
(0.005)\end{array}$ & $\begin{array}{c}0.012 \\
(0.009)\end{array}$ & $\begin{array}{c}0.027 * * * \\
(0.008)\end{array}$ & $\begin{array}{c}0.015 \\
(0.011)\end{array}$ & $\begin{array}{c}0.025 * * * \\
(0.008)\end{array}$ \\
\hline Minority & $\begin{array}{c}0.028 \\
(0.225)\end{array}$ & $\begin{array}{c}0.478 * * \\
(0.204)\end{array}$ & $\begin{array}{l}-0.027 \\
(0.312)\end{array}$ & $\begin{array}{l}0.541^{*} \\
(0.297)\end{array}$ & $\begin{array}{l}-0.022 \\
(0.351)\end{array}$ & $\begin{array}{c}0.395 \\
(0.303)\end{array}$ \\
\hline $\begin{array}{l}\text { Proportion of } \\
\text { children living with } \\
\text { parents in the local } \\
\text { city }\end{array}$ & $\begin{array}{c}3.159 * * * \\
(0.482)\end{array}$ & $(0.470)$ & $(0.697)$ & $3.549 * * *$ & $\begin{array}{c}3.196 * * * \\
(0.748)\end{array}$ & $\begin{array}{c}2.857 * * * \\
(0.720)\end{array}$ \\
\hline $\begin{array}{l}\text { Region of residence } \\
\text { Eastern China }\end{array}$ & & & & & & \\
\hline Middle China & $\begin{array}{c}-0.448 * * * \\
(0.109)\end{array}$ & $\begin{array}{c}-0.535 * * * \\
(0.096)\end{array}$ & $\begin{array}{l}-0.273^{*} \\
(0.155)\end{array}$ & $\begin{array}{c}-0.482 * * * \\
(0.136)\end{array}$ & $\begin{array}{c}-0.541 * * * \\
(0.172)\end{array}$ & $\begin{array}{c}-0.521 * * * \\
(0.148)\end{array}$ \\
\hline Western China & $\begin{array}{c}-0.395^{* * *} \\
(0.124)\end{array}$ & $\begin{array}{c}-0.487 * * * \\
(0.108)\end{array}$ & $\begin{array}{c}-0.427 * * \\
(0.176)\end{array}$ & $\begin{array}{c}-0.479 * * * \\
(0.157)\end{array}$ & $\begin{array}{l}-0.301 \\
(0.189)\end{array}$ & $\begin{array}{c}-0.388 * * \\
(0.162)\end{array}$ \\
\hline
\end{tabular}




\begin{tabular}{lcccccc} 
Constant & $24.888 * * *$ & $31.295 * * *$ & $22.884 * * *$ & $36.187 * * *$ & $26.471 * * *$ & $33.101 * * *$ \\
& $(5.540)$ & $(4.805)$ & $(8.011)$ & $(7.501)$ & $(9.511)$ & $(7.258)$ \\
Censored obs. & 575 & 834 & 227 & 318 & 348 & 516 \\
Uncensored obs. & 473 & 512 & 295 & 225 & 178 & 187 \\
Observations & 1048 & 1346 & 522 & 643 & 526 & 703 \\
\hline
\end{tabular}

Source: Authors' estimates from the 2002 CHIP data.

Note: The dependent variable in the first stage takes the value of 1 if the adult child is coresiding with parents, otherwise it takes the value of zero.

Children aged 25-35 and their co-residing parents aged 50-60. Three-year average of income of parents is used. 
Table 8. Intergenerational income elasticity with co-residence bias corrected for, parents aged between 50 and 70 . The 2002 sample.

\begin{tabular}{|c|c|c|c|c|c|c|}
\hline \multicolumn{7}{|l|}{ Second Stage: } \\
\hline Income of children & Sons and & Jaughters & Sc & & Dau & hters \\
\hline Father's income & $\begin{array}{c}0.487 * * * \\
(0.053)\end{array}$ & & $\begin{array}{c}0.537 * * * \\
(0.068)\end{array}$ & & $\begin{array}{c}0.414 * * * \\
(0.084)\end{array}$ & \\
\hline Mother's income & & $\begin{array}{c}0.438 * * * \\
(0.056)\end{array}$ & & $\begin{array}{c}0.446 * * * \\
(0.072)\end{array}$ & & $\begin{array}{c}0.419 * * * \\
(0.091)\end{array}$ \\
\hline Intercept & $\begin{array}{c}4.597 * * * \\
(0.496)\end{array}$ & $\begin{array}{l}5.229 * * * \\
(0.510)\end{array}$ & $\begin{array}{l}4.141 * * * \\
(0.633)\end{array}$ & $\begin{array}{l}5.138 * * * \\
(0.647)\end{array}$ & $\begin{array}{c}5.266^{* * * *} \\
(0.787)\end{array}$ & $\begin{array}{c}5.427 * * * \\
(0.824)\end{array}$ \\
\hline Inverse Mill's ratio & $\begin{array}{c}-0.207 * * * \\
(0.056)\end{array}$ & $\begin{array}{c}-0.184 * * * \\
(0.055)\end{array}$ & $\begin{array}{c}-0.196 * * \\
(0.077)\end{array}$ & $\begin{array}{c}-0.155^{* *} \\
(0.074)\end{array}$ & $\begin{array}{c}-0.258 * * * \\
(0.082)\end{array}$ & $\begin{array}{c}-0.245 * * * \\
(0.082)\end{array}$ \\
\hline $\begin{array}{l}\text { First stage: } \\
\text { Living } \\
\text { parents }\end{array}$ & & & & & & \\
\hline Children's age & $\begin{array}{c}-1.437 * * * \\
(0.261)\end{array}$ & $\begin{array}{l}-1.702^{* * * *} \\
(0.257)\end{array}$ & $\begin{array}{c}-1.357 * * * \\
(0.392)\end{array}$ & $\begin{array}{c}-1.884 * * * \\
(0.403)\end{array}$ & $\begin{array}{c}-1.862 * * * \\
(0.405)\end{array}$ & $\begin{array}{c}-1.890 * * * \\
(0.379)\end{array}$ \\
\hline $\begin{array}{l}\text { Children's age } \\
\text { squared }\end{array}$ & $\begin{array}{c}0.020 * * * \\
(0.004) \\
0.269 \\
(0.165)\end{array}$ & $\begin{array}{c}0.024 * * * \\
(0.004) \\
0.445 * * * \\
(0.161)\end{array}$ & $\begin{array}{c}0.018 * * * \\
(0.006) \\
0.270 \\
(0.236)\end{array}$ & $\begin{array}{c}0.027 * * * \\
(0.007) \\
0.512 * * \\
(0.231)\end{array}$ & $\begin{array}{c}0.026 * * * \\
(0.007) \\
0.294 \\
(0.250)\end{array}$ & $\begin{array}{c}0.027 * * * \\
(0.006) \\
0.383 \\
(0.242)\end{array}$ \\
\hline $\begin{array}{l}\text { Proportion of } \\
\text { children living with } \\
\text { parents in the local } \\
\text { city }\end{array}$ & $(0.351)$ & $3.051 * * *$ & $3.059 * * *$ & $3.017 * * *$ & $2.789 * * *$ & $(0.593)$ \\
\hline \multicolumn{7}{|l|}{$\begin{array}{l}\text { Region of residence } \\
\text { Eastern China }\end{array}$} \\
\hline Middle China & $\begin{array}{c}-0.381 * * * \\
(0.079)\end{array}$ & $\begin{array}{c}-0.470 * * * \\
(0.077)\end{array}$ & $\begin{array}{c}-0.329 * * * \\
(0.110)\end{array}$ & $\begin{array}{c}-0.466 * * * \\
(0.108)\end{array}$ & $\begin{array}{c}-0.474 * * * \\
(0.127)\end{array}$ & $\begin{array}{c}-0.468 * * * \\
(0.119)\end{array}$ \\
\hline Western China & $\begin{array}{c}-0.353 * * * \\
(0.091)\end{array}$ & $\begin{array}{c}-0.478 * * * \\
(0.088)\end{array}$ & $\begin{array}{c}-0.365^{* * *} \\
(0.127)\end{array}$ & $\begin{array}{c}-0.510 * * * \\
(0.125)\end{array}$ & $\begin{array}{c}-0.336 * * \\
(0.142)\end{array}$ & $\begin{array}{c}-0.427 * * * \\
(0.135)\end{array}$ \\
\hline Constant & $\begin{array}{l}27.743 * * * \\
(3.922)\end{array}$ & $\begin{array}{c}31.839 * * * \\
(3.898)\end{array}$ & $\begin{array}{l}27.284 * * * \\
(5.959)\end{array}$ & $\begin{array}{l}35.374 * * * \\
(6.189)\end{array}$ & $\begin{array}{l}33.765 * * * \\
\quad(6.024)\end{array}$ & $\begin{array}{l}34.520 * * * \\
\quad(5.685)\end{array}$ \\
\hline $\begin{array}{l}\text { Censored obs. } \\
\text { Uncensored obs. } \\
\text { Observations }\end{array}$ & $\begin{array}{c}1231 \\
691 \\
1922\end{array}$ & $\begin{array}{c}1360 \\
679 \\
2039\end{array}$ & $\begin{array}{l}483 \\
450 \\
933\end{array}$ & $\begin{array}{l}535 \\
435 \\
970\end{array}$ & $\begin{array}{l}748 \\
241 \\
989\end{array}$ & $\begin{array}{c}825 \\
244 \\
1069\end{array}$ \\
\hline
\end{tabular}

Source: Authors' estimates from the 2002 CHIP data.

Note: The dependent variable in the first stage takes the value of 1 if the adult child is co-residing with parents; otherwise it takes the value of zero.

Children aged 25-35 and their co-residing parents aged 50-70. Three-year average of income of parents is used. 
Table 9

A Survey of estimates of intergenerational income persistency (sons - fathers) in various countries.

$\begin{array}{lll}\text { Country } & \text { Source } & \text { Elasticity }\end{array}$

Preferred estimates for eleven high-income countries (according to survey by Blanden, 2011).

US

Solon (1992) $\quad 0.41(0.09)$

UK

Dearden, Machin and Reed $0.37(0.05)$

(1977) (scaled) and averaged

with Nicoletti and Ermish

(2007)

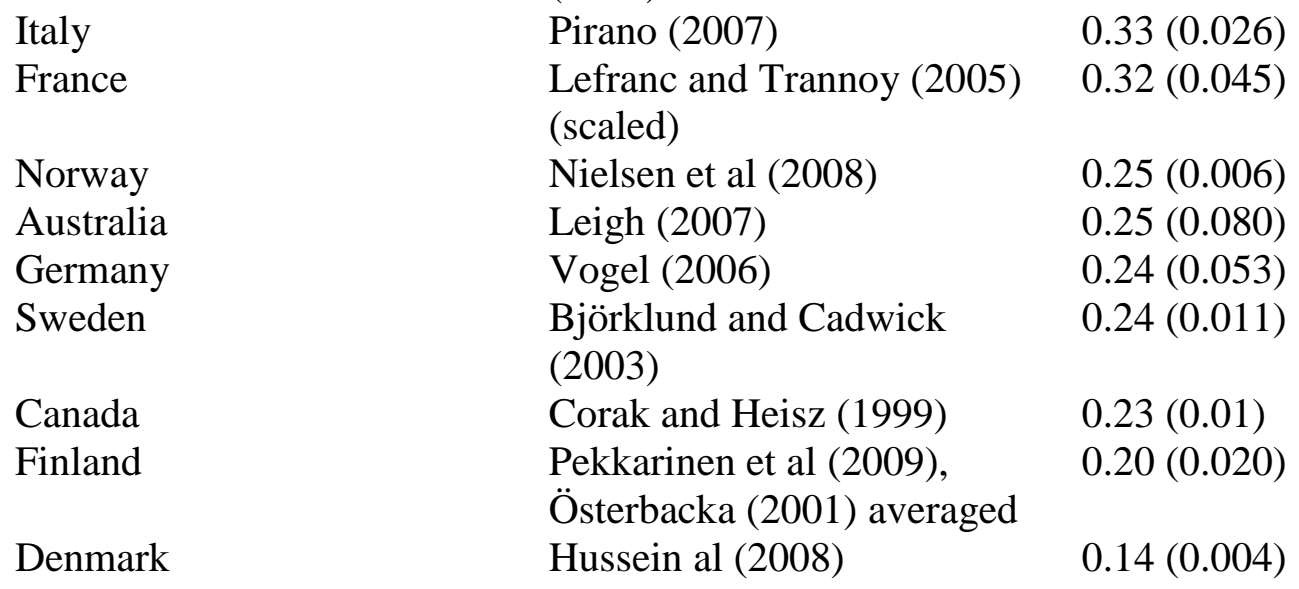

Estimates for some developing countries, typically based on small samples

$\begin{array}{lll}\text { Ecuador } & \text { Grawe }(2004) \text { (scaled) } & 0.85(0.294) \\ \text { Peru } & \text { Grawe }(2004) \text { (scaled) } & 0.50(0.172) \\ \text { Malaysia } & \text { Grewe }(2004) \text { (scaled) } & 0.40(0.215) \\ \text { Nepal } & \text { Grewe }(2004) \text { (scaled) } & 0.24(0.197) \\ \text { Pakistan } & \text { Grewe }(2004) \text { (scaled) } & 0.18(0.301)\end{array}$

Recent estimates for some additional countries

Brazil

Ferreira and Veloso (2006) $\quad 0.41(0.01)-0.55(0.01)$

(scaled)

Dunn (2007) (scaled) $\quad 0.52(0.011)$

Chile Nunez and Miranda (2010)

$0.43(0.054)$ to $0.57(0.065)$

Japan

(scaled), one year income

Ueda (2009) (scaled) one

$0.31(0.057)$ to $0.35(0.075)$

year income (for married

sons).

Spain

Pascual (2009)

0.32

Urban China

This study, preferred

$0.47(0.083)$ and $0.53(0.082)$

estimates based on three-year

accounting period and

corrected for co-residency

bias 
